\title{
DAYA SAING INDUSTRI TAHU - TEMPE DI KELURAHAN KLEAK KECAMATAN MALALAYANG KOTA MANADO
}

\author{
Anggita Hartati Sitorus \\ Leonardus Ricky Rengkung \\ Elsje Pauline Manginsela
}

Naskah diterima melalui email dari Jurnal Ilmiah agrisosioekonomi@unsrat.ac.id

Disetujui diterbitkan

: Jumat, 12 April 2019

: Kamis, 25 April 2019

\begin{abstract}
This study aims to analyze the competitiveness of the "ABC" Tofu - Tempe industry and the "XYZ" Tofu - Tempe industry, Kleak Village, Malalayang District, Manado City, North Sulawesi. This research was conducted for three months from October to December 2018. The data used were primary data and secondary data. The sampling in this study was consumers from the Tahu-Tempe Industry in Kelak Village. This research uses accidentally sampling technique. Primary data collection is done by interviews using questionnaires. While secondary data was obtained from financial records from 2 Tofu - Tempe Industries in Kleak Village, skripsi from Faculty of Agriculture Library, Sam Ratulangi University (Unsrat), books available at local bookstores and the Internet through Google Scholar to access articles from various scientific journals and thesis from various universities. This study uses the Importance Performance Analysis (IPA) analysis. The results showed that the price offered by the Tofu Industry - Tempe "ABC" and Tahu - Tempe "XYZ" showed a different assessment, the industry "ABC" was considered very affordable and taste was satisfied but the quality was not satisfactory and the capacity and benefits were considered not too important . While the industry "XYZ" shows the price offered is not satisfactory from all aspects. In terms of good products for the Tofu Industry - Tempe "ABC" and Tahu - Tempe "XYZ" showed different levels of satisfaction where the "ABC" industry for consumers satisfies in terms of cleanliness and completeness but in terms of unsatisfactory cleanliness and the availability of raw materials is very unsatisfactory but for the display of satisfying products but considered not important for consumers, while the industry "XYZ" shows satisfying product taste but from the aspect of cleanliness, product availability and completeness in the presentation of products is very important for consumers but not satisfying while the physical appearance of the product is less important or something expected by consumers. Then in terms of the place used by the Tofu - Tempe Industry "ABC" and the Tahu-Tempe Industry "XYZ" the level of cleanliness of the room that is still less clean, the comfort of the room that is still affordable from smoked tofu - Tempe and the noise of the engine, the physical appearance of the room is also not good and must be repaired for the " $A B C$ " industry, the "ABC" industry is less competitive with the industry "XYZ", while the availability of production equipment and very strategic locations shows very satisfied and good because many tools are used and marketing locations very strategic close to boarding houses, restaurants and markets. In terms of services provided by Tahu - Tempe Industry workers "ABC" and Tahu -Tempe Industry "XYZ" both from speed, alertness, knowledge and friendliness have been very satisfying to consumers, only for the "ABC" industry the physical appearance of these workers is not good from dress and neatness that is shown to not satisfy the buyer but is very important for consumers, while for the industry "XYZ" consumers value some already satisfactory from dress and neatness and some are unsatisfactory from dress and neatness and this aspect is considered very important for consumers. *eprm*
\end{abstract}

Keywords: Industrial competitiveness, tofu-tempe, Importance Performance Analysis (IPA), Manado City

\section{ABSTRAK}

Penelitian ini bertujuan untuk menganalisis daya saing industri Tahu - Tempe "ABC" dan industri Tahu - Tempe "XYZ" Kelurahan Kleak Kecamatan Malalayang Kota Manado, Sulawesi Utara. Penelitian ini dilakukan selama tiga bulan dari bulan Oktober sampai bulan Desember 2018. Data yang digunakan adalah data primer dan data sekunder. Pengambilan sampel dalam penelitian ini adalah konsumen dari Industri Tahu- Tempe di Kelurahan Kleak. Penelitian ini menggunakan teknik accidentally sampling. Pengumpulan data primer dilakukan dengan wawancara yang menggunakan kuesioner. Sedangkan data sekunder diperoleh dari catatan keuangan dari 2 Industri Tahu - Tempe di Kelurahan Kleak, Perpustakaan Fakultas Pertanian, Universitas Sam Ratulangi (Unsrat), buku-buku yang tersedia di toko buku lokal dan Internet melalui google cendekia untuk mengakses artikel dari berbagai jurnal ilmiah dan skripsi dari berbagai perguruan tinggi. Penelitian ini menggunakan analisis Importance Performance Analysis (IPA). Hasil penelitian menunjukkan bahwa harga yang ditawarkan Industri Tahu - Tempe "ABC" dan Tahu - Tempe "XYZ" menunjukan penilaian yang berbeda, industri " $\mathrm{ABC}$ " dinilai sangat terjangkau dan cita rasa dinilai puas namun kualitas tidak memuaskan serta kapasitas dan manfaat dinilai tidak terlalu penting. Sedangkan industri "XYZ" menunjukkan harga yang ditawarkan tidak memuaskan dari semua aspek. Dari segi produk baik untuk Industri Tahu - Tempe "ABC" dan Tahu - Tempe "XYZ" menunjukkan tingkat kepuasan yang berbeda dimana industri "ABC" terhadap konsumen memuaskan dari segi kebersihan dan kelengkapan namun dari segi kebersihan tidak memuaskan serta ketersediaan bahan baku sangat tidak memuaskan namun untuk tampilan produk memuaskan tetapi dinilai tidak penting bagi konsumen, sedangkan industri "XYZ" menunjukkan cita rasa produk memuaskan namun dari aspek kebersihan, ketersediaan produk dan kelengkapan dalam penyajian produk sangat penting bagi konsumen tetapi tidak memuaskan sedangkan tampilan fisik produk kurang penting atau bukan sesuatu yang diharapkan oleh konsumen. Kemudian dari segi tempat yang digunakan Industri Tahu - Tempe "ABC" dan Industri Tahu -Tempe "XYZ" kurang baik dari tingkat kebersihan ruangan yang masih kurang bersih, kenyamanan ruangan yang masih terjangkau dari asap oleh olahan Tahu - Tempe dan suara mesin yang ribut, tampilan fisik ruangan juga kurang baik dan harus diperbaiki untuk Industri “ABC”, maka Industri “ABC” kalah saing dengan Industri "XYZ”, sedangkan ketersediaan peralatan produksi dan lokasi yang sangat strategis menunjukan sangat puas dan baik karena alat yang digunakan banyak dan lokasi pemasaran sangat strategis dekat dengan tempat kost, rumah makan dan pasar. Dari segi pelayanan yang diberikan oleh pekerja Industri Tahu - Tempe "ABC" dan Industri Tahu -Tempe "XYZ" baik itu dari kecepatan , kesigapan, pengetahuan dan keramahan sudah sangat memuaskan konsumen, hanya untuk industri " $\mathrm{ABC}$ " penampilan fisik dari pekerja tersebut kurang baik dari berpakaian dan kerapian yang ditunjukan belum memuaskan pembeli namun sangat penting bagi konsumen, sedangkan untuk industri "XYZ" konsumen menilai sebagian sudah memuaskan dari berpakaian dan kerapian dan sebagian tidak memuaskan dari berpakaian dan kerapian dan aspek ini dianggap sangat penting bagi konsumen. *eprm*

Kata kunci: Daya saing industri, tahu-tempe, Importance Performance Analysis (IPA), Kota Manado 


\section{PENDAHULUAN}

\section{Latar Belakang}

Pangan merupakan kebutuhan dasar utama bagi manusia yang harus dipenuhi setiap saat. Tersedianya pangan yang cukup, aman, bermutu dan bergizi merupakan prasyarat utama yang harus dipenuhi dalam upaya mewujudkan insan yang berharkat dan bermartabat serta mempunyai basis sumberdaya manusia yang berkualitas. Hak untuk memperoleh pangan merupakan salah satu hak asasi manusia, sebagaimana tersebut dalam pasal 27 UUD 1945 maupun dalam Deklarasi Roma tahun 1996.

Salah satu komoditas pangan penghasil protein nabati yang dikenal masyarakat adalah kedelai. Dalam kelompok tanaman pangan, kedelai merupakan komoditas terpenting ketiga setelah padi dan jagung. Komponen terpenting kedua dari pakan konsentrat (setelah jagung) adalah bungkil kedelai (Tangendjaja dan ilham 2003). Selain itu, kedelai juga merupakan komoditas palawija yang kaya akan protein. Kedelai berperan sebagai sumber protein nabati yang sangat penting dalam rangka peningkatan gizi masyarakat, karena selain aman bagi kesehatan juga relatif murah dibandingkan sumber protein hewani. Direktorat Jenderal Tanaman Pangan memperkirakan konsumsi kedelai saat ini sekitar 1,8 juta ton (Ditjentan 2004).

Di Sulawesi Utara, sebagaimana daerahdaerah lainnya di Indonesia perindustrian telah menjadi salah satu sektor potensial yang dimiliki sebagai salah satu sumberdaya ekonominya. Khususnya Kota Manado dewasa ini terus menggalakan sektor industri untuk menopang meningkatan pendapatan dan kesejahteraaan masyarakat lewat sektor industri kecil. Dengan adanya penggalakan tersebut, industri Tahu Tempe mempunyai prospek pengembangan yang cukup besar dan ini di tunjang oleh ketersediaan bahan baku yaitu kedelai, sumber daya manusia (TK), kesempatan berusaha dan peluang pasar yang cukup terbuka.

Salah satu produk agroindustri yang dikelola adalah Tahu -Tempe. Di Kelurahan Kleak tepatnya di Lingkungan 1 terdapat beberapa industri Tahu - Tempe yaitu Industri Tahu-Tempe "ABC" dan Industri Tahu -Tempe "XYZ". Industri yang bertepat di Kelurahan Kleak ini sudah lama berdiri dan sudah turun temurun dari orang tua. Selain itu Tahu-Tempe ini sudah dipasarkan di beberapa lokasi di Kota Manado, yakni di Supermarket /swalayan, Rumah makan, Pedagang Kecil (Penjualan nasi kuning dan gorengan), Restoran dan di pasar yang ada di Kota Manado. Dalam hal ini pemasaran Tahu Tempe buatan Kelurahan Kleak terus berupaya untuk mempertahankan perannya dipasar sehingga tetap menjaga posisinya dalam persaingan.

Tahu - Tempe buatan Kelurahan Kleak terdapat persaingan dalam pemasaran. Persaingan yang ada antar industri. Persaingan antar industri terjadi antar industri Tahu-Tempe Batu Kota, Winangun, Bahu dan Tahu - Tempe Kelurahan Kleak. Industri Tahu - Tempe bersaing disamping rasa, kualitas dan juga harga. Situasi persaingan yang begitu tinggi saat ini telah memaksa suatu industri untuk lebih meningkatkan daya saingnya hingga mencapai tingkatan superior competitive advantage diantara pesaing-pesaingnya. Hal lainnya, suatu industri dituntut untuk terus meningkatkan kapasitas dalam usaha memuaskan kebutuhan konsumennya (Musa Hubeis, 2002).

Upaya pemasaran dan pasar sasaran dalam bisnis industri yang dipusatkan pada kebutuhan pelanggan atau konsumen, pada akhirnya dapat membentuk kepuasan pelanggannya dimana konsumen yang sekarang merupakan konsumen yang sudah tumbuh dan berkembang, selain itu kuat tidaknya fokus pelanggan bisnis industri sangat tergantung pada bagaimana baiknya pemahaman industri atas pesaingpesaing kuncinya serta kekuatan kompetitifnya. Persaingannya juga akan terus berubah karena perkembangan dan terdapatnya kemajuan teknologi baru. Hasil kegagalan dalam sebuah ketidakpuasan konsumen meng-hasilkan keluhan, pemberitaan yang negatif dan keputusan tidak membeli produk atau jasa dari penjual yang sama (Kim et al., 2004).

Dengan demikian, perlu dilakukan analisis tentang kepentingan/ekspektasi konsumen terhadap faktor-faktor yang menyertai pelayanan Industri Tahu - Tempe di Kelurahan Kleak dan bagaimana kinerja Industri Tahu - Tempe di Kelurahan Kleak dalam usaha memenuhi harapan konsumen sehingga konsumen memperoleh kepuasan. 


\section{Rumusan Masalah}

Berdasarkan latar belakang yang telah diuraikan maka rumusan masalah dalam penelitian ini adalah bagaimana daya saing Industri Tahu - Tempe di Kelurahan Kleak Kecamatan Malalayang Kota Manado ?

\section{Tujuan Penelitian}

Tujuan penelitian ini yaitu melakukan pengukuran bagaimana daya saing Industri Tahu - Tempe di Kelurahan Kleak Kecamatan Malalayang Kota Manado.

\section{Manfaat Penelitian}

Manfaat dalam penelitian ini adalah :

1. Bagi penulis adalah untuk meningkatkan pengetahuan tentang daya saing Industri Tahu - Tempe.

2. Bagi pemilik Industri Tahu - Tempe diharapkan menjadi bahan informasi agar mampu bersaing.

3. Bagi yang membaca, dapat menjadi sumber informasi dan masukan yang dapat digunakan dalam penelitian selanjutnya serta menambah wawasan yang lebih luas.

\section{METODE PENELITIAN}

\section{Lokasi dan Waktu Penelitian}

Lokasi tempat penelitian dilakukan adalah di Kelurahan Kleak, Kecamatan Malalayang, Kota Manado. Penelitian dilakukan selama tiga bulan yaitu dari bulan Oktober sampai bulan Desember 2018.

\section{Metode Pengambilan Sampel}

Pengambilan sampel dalam penelitian ini adalah konsumen Industri Tahu- Tempe di Kelurahan Kleak, Kecamatan Malalayang. Penelitian ini menggunakan teknik secara tanpa sengaja (Accidental Sampling). Teknik penentuan sampel ini berdasarkan kebetulan, yaitu siapa saja yang secara kebetulan bertemu dengan peneliti dapat digunakan sebagai sampel (Nyoman Dantes 2012).

\section{Metode Pengumpulan Data}

Data yang digunakan meliputi data primer dan data sekunder. Pengumpulan data primer dilakukan dengan menggunakan kuesioner yang merupakan suatu pengumpulan data dengan teknik wawancara langsung kepada responden. Sedangkan untuk data sekunder atau data yang diperoleh secara tidak langsung dengan metode dokumentasi diperoleh dari 2 Industri Tahu - Tempe di Kelurahan Kleak, Perpustakaan Fakultas Pertanian Unsrat, buku-buku yang tersedia di toko buku lokal dan Internet seperti google untuk mengakses artikel dari berbagai jurnal ilmiah.

\section{Konsep Pengukuran Variabel}

Pengukuran daya saing dari usaha ini didasarkan pada variabel-variabel berikut yang diukur dengan menggunakan skala Likert dengan kategori lima skala yaitu 1 (sangat tidak puas), 2 (tidak puas), 3 (cukup), 4 (puas) dan 5 (sangat puas).

Variabel yang diukur dan digunakan dalam penelitian ini adalah :

1. Karakteristik Responden :

a. Umur responden (tahun)

b. Jenis kelamin, yaitu laki-laki dan perempuan $(\mathrm{L} / \mathrm{P})$.

c. Tingkat pendidikan (SD, SMP, SMA, Perguruan Tinggi)

d. Jenis mata pencaharian, yaitu dilihat dari jenis pekerjaan yang dilakukan oleh responden.

2. Harga

Indikator variabel harga adalah :

a. Terjangkau atau tidaknya harga

b. Kesesuaian harga dengan ukuran

c. Kesesuaian harga dengan cita rasa

d. Kesesuaian harga dengan manfaat

e. Kesesuaian harga dengan kualitas

3. Produk

Indikator variabel produk adalah:

a. Kebersihan dalam penyajian

b. Ketersediaan produk Tahu-Tempe

c. Cita rasa produk

d. Tampilan fisik produk

e. Tingkat kepuasan dari konsumen

4. Tempat

Indikator variabel tempat adalah:

a. Kebersihan ruangan

b. Kenyamanan ruangan

c. Tampilan fisik ruangan 
d. Sumber daya fisik yaitu menggambarkan adanya ketersediaan peralatan produksi yang diperlukan untuk menunjang perkembangan industri Tahu - Tempe atau kelengkapan sarana dan fasilitas yang dimiliki

e. Lokasi yang strategis.

5. Pelayanan

Indikator variabel pelayanan adalah:

a. Kualitas pelayanan yaitu kecepatan dalam melayani pembelian Tahu-Tempe

b. Daya tanggap yaitu kesigapan pekerja dalam memberikan pelayanan dan menangani keluhan para konsumen Tahu-Tempe

c. Pengetahuan pekerja terhadap produk Tahu-Tempe

d. Penampilan fisik yaitu kerapian berpakaian dari perkerja

e. Empati yaitu keramahan pekerja dalam melayani konsumen.

\section{Analisis Data}

Menurut Bogdan yang dikutip oleh Sugiyono (2009), analisis data merupakan proses mencari dan menyusun secara sistimatis data yang diperoleh dari hasil angket, catatan lapangan, dan bahan-bahan lain sehingga dapat mudah dipahami dan temuannya dapat dinformasikan kepada orang lain. Analisis data yang digunakan dalam penelitian ini yaitu menggunakan analisis Importance Performance Analysis (IPA). Importance Performance Analysis (IPA) secara konsep merupakan suatu model multiatribut. Teknik ini mengidentifikasi kekuatan dan kelemahan penawaran pasar dengan menggunakan dua kriteria yaitu kepentingan relatif atribut dan kepuasan konsumen.

\section{HASIL DAN PEMBAHASAN}

\section{Deskripsi Umum Industri Tahu - Tempe "ABC" dan Industri Tahu - Tempe "XYZ" \\ Industri Tahu - Tempe "ABC" terletak di} Kelurahan Kleak, Kecamatan Malalayang, Manado Provinsi Sulawesi Utara. Sarana transportasi ke kawasan ini kurang baik dengan kondisi jalan yang kurang lebar namun dapat dilalui oleh kendaraan besar dan kecil, selain itu daerah ini memiliki fasilitas yang diperlukan oleh industri seperti fasilitas listrik oleh PLN dan fasilitas air. Industri Tahu - Tempe "ABC" menghasilkan produk berupa tahu dan tempe, didirikan oleh Bapak Gendon, Industri Tahu Tempe "ABC" berlokasi di jalan Karombasan Utara, Lingkungan 1, Kelurahan Kleak, Kecamatan Malalayang. Tenaga Kerja pada industri TahuTempe "ABC" berjumlah 6 orang, yang mana pada bagian pembuatan tahu berjumlah 4 orang dan pada pembuatan Tempe 2 orang.

Sedangkan Industri Tahu - Tempe "XYZ" terletak di Kelurahan Kleak, Kecamatan Malalayang, Manado Provinsi Sulawesi Utara dan sudah turun temurun oleh orang tua, namun pemilik sekarang bernama Suyatmo. Industri Tahu - Tempe "XYZ" sekarang sudah memasarkan hasil produknya ke pasar, Restoran (Rumah makan), dan swalayan/supermarket. Tenaga kerja pada Industri Tahu - Tempe "XYZ" berjumlah 7 orang, yang mana pada bagian pembuatan tahu berjumlah 4 orang dan pada pembuatan tempe berjumlah 3 orang.

\section{Karakteristik Responden}

Karakteristik responden yaitu untuk memberikan gambaran tentang keadaan diri responden. Responden dalam penelitian ini yaitu konsumen yang secara kebetulan bertemu dan membeli produk Tahu - Tempe yang berjumlah 20 orang. Gambaran keadaan responden meliputi umur responden (tahun), jenis kelamin, tingkat pendidikan dan pekerjaan.

\section{Umur Responden}

Banyak pengunjung di Industri Tahu Tempe "ABC" dam Industri Tahu - Tempe "XYZ" bervariasi berdasarkan umur. Umur juga seringkali menjadi penentu dalam pengambilan keputusan pembelian. Berikut tabel umur responden :

\begin{tabular}{ccccc}
$\begin{array}{c}\text { Tabel 1. Umur Responden Industri Tahu - Tempe } \\
\text { Golongan Umur } \\
\text { Responden (Tahun) }\end{array}$ & \multicolumn{2}{l}{ Jumlah Responden } & \multicolumn{2}{c}{ Persentase } \\
\hline & ABC & XYZ & ABC & XYZ \\
\hline $10-20$ & 2 & 1 & 20 & 10 \\
$21-30$ & 4 & 4 & 40 & 50 \\
$31-40$ & 2 & 2 & 20 & 0 \\
$41-50$ & 2 & 2 & 20 & 30 \\
$>50$ & 0 & 0 & 0 & 10 \\
\hline Jumlah & $\mathbf{1 0}$ & $\mathbf{1 0}$ & $\mathbf{1 0 0}$ & $\mathbf{1 0 0}$ \\
\hline Sumber $:$ Diolah dari Data Primer, 2018 & & &
\end{tabular}

Tabel 1 menunjukkan bahwa responden terbanyak pada Industri " $\mathrm{ABC}$ " adalah berumur 21 - 30 tahun yaitu 4 orang (45\%) dan responden terbanyak pada Industri "XYZ" asalah berumur $21-30$ tahun yaitu 5 orang (50\%), sedangkan persentasi terkecil pada Industri "ABC" yaitu pada umur $>50$ tahun yaitu 0 orang $(0 \%)$, sedangkan persentasi terkecil pada Industri "XYZ" yaitu berumur $31-40$ tahun yaitu 0 orang $(0 \%)$. Ini menunjukkan responden untuk 
kedua Industri "ABC" dan Industri "XYZ" terbanyak pada umur 21 - 30 tahun, pada umur ini lebih banyak membeli untuk dimasak dan dijual.

\section{Jenis Kelamin Responden}

Jenis Kelamin responden bisa menjadi penentu atas tindakan atau perilaku responden dalam membeli barang atau jasa. Berikut Tabel jenis kelamin responden:

Tabel 2. Jenis Kelamin Responden Industri Tahu - Tempe Jenis Kelamin Jumlah Responden Persentase

\begin{tabular}{lllll} 
& ABC & XYZ & ABC & XYZ \\
\hline Laki - laki & 3 & 2 & 30 & 20 \\
Perempuan & 7 & 8 & 70 & 80 \\
\hline Jumlah & $\mathbf{1 0}$ & $\mathbf{1 0}$ & $\mathbf{1 0 0}$ & $\mathbf{1 0 0}$
\end{tabular}

Sumber : Diolah dari Data Primer, 2018

Tabel 2 menunjukkan bahwa untuk jenis kelamin perempuan memiliki jumlah yang lebih banyak dibandingkan dengan jenis kelamin laki - laki yaitu laki - laki 3 orang $(30 \%)$ untuk Industri "ABC" dan laki - laki 2 orang (20\%) pada Industri "XYZ" sedangkan untuk kelamin perempuan 7 orang $(70 \%)$ pada Industri "ABC" dan kelamin perempuan 8 orang $(80 \%)$ pada Industri "XYZ". Hal ini menunjukkan bahwa perempuan lebih banyak membeli Tahu Tempe di Industri Tahu - Tempe untuk keperluan dirumah sebagai makanan pengganti lauk pauk ataupun untuk dijual.

\section{Tingkat Pendidikan Responden}

Pendidikan seseorang seringkali menjadi penentu perilaku seseorang dalan pengambilan keputusan pembelian. Berikut tabel tingkat pendidikan responden :

\begin{tabular}{lcccc}
\multicolumn{2}{c}{ Tabel 3. Tingkat Pendidikan Responden Industri Tahu - Tempe } \\
\hline $\begin{array}{c}\text { Tingkat } \\
\text { Pendidikan }\end{array}$ & Jumlah Responden & \multicolumn{2}{c}{ Persentase } \\
& ABC & XYZ & ABC & XYZ \\
\hline SMA/SMK & 7 & 8 & 70 & 80 \\
D3 & 2 & 0 & 20 & 0 \\
S1 & 1 & 2 & 10 & 20 \\
\hline Jumlah & $\mathbf{1 0}$ & $\mathbf{1 0}$ & $\mathbf{1 0 0}$ & $\mathbf{1 0 0}$ \\
\hline
\end{tabular}

Tabel 3 menunjukkan bahwa responden kedua Industri Tahu - Tempe terbanyak adalah lulusan Sekolah Menengah Atas/ Sekolah Menengah Kejuruan dengan jumlah responden 7 orang $(70 \%)$ di Industri "ABC" dan 0 orang $(80 \%)$ di Industri "XYZ" sedangkann responden terkecil yaitu lulusan strata satu dengan jumlah 1 orang (10\%) pada Industri "ABC" dan responden terkecil pada Industri
"XYZ" yaitu lulusan D3 dengan jumlah 0 orang $(0 \%)$. Ini menunjukkan bahwa responden berdasarkan pendidikan kebanyakan adalah berpendidikan SMA/SMK.

\section{Pekerjaan Responden}

Pekerjaan pada umumnya mencerminkan satu bentuk perilaku pembelian terhadap produk atau jasa. Berikut Tabel pekerjaan responden :

Tabel 4. Pekerjaan Responden Industri Tahu - Tempe

\begin{tabular}{lcrrc}
\hline Jenis Pekerjaan & \multicolumn{2}{l}{$\begin{array}{l}\text { Jumlah } \\
\text { Responden }\end{array}$} & & Persentase \\
\cline { 2 - 5 } & ABC & XYZ & ABC & XYZ \\
\hline IRT (Ibu Rumah & 2 & 2 & 20 & 20 \\
Tangga) & & & & \\
Pelajar/Mahasiswa & 2 & 5 & 20 & 50 \\
PNS & 1 & 0 & 10 & 0 \\
Swasta & 3 & 1 & 30 & 10 \\
Wirausaha & 2 & 2 & 20 & 20 \\
\hline Jumlah & $\mathbf{1 0}$ & $\mathbf{1 0}$ & $\mathbf{1 0 0}$ & $\mathbf{1 0 0}$ \\
\hline
\end{tabular}

Sumber : Diolah dari Data Primer, 2018

Tabel 4 menunjukkan bahwa responden terbanyak pada Industri "ABC" adalah Swasta dengan jumlah 3 orang (30\%) dan pada Industri "XYZ" adalah Pelajar/Mahasiswa dengan jumlah 5 orang $(50 \%)$ sedangkan responden terkecil adalah PNS dengan jumlah 1 orang $(0 \%)$ di Industri "ABC" dan 0 orang $(0 \%)$ di Industri "XYZ". Ini menunjukkan bahwa kebanyakan responden adalah Pelajar/Mahasiswa dan Swasta.

Pengukuran Daya Saing Pada Industri Tahu Tempe "ABC" Dan Industri Tahu - Tempe "XYZ" Pengukuran daya saing pada Industri Tahu Tempe "ABC" dan Industri Tahu - Tempe "XYZ" dilakukan dengan menggunkan analisis IPA (Importance Performance Analysis) dengan beberapa variabel yaitu harga, produk, tempat dan pelayanan. Hasil posisi daya saing dari kedua Industri tersebut dapat dijelaksan sebagai berikut :

Harga

Harga yang merupakan satu-satunya unsur bauran pemasaran yang seringkali dijadikan sebagai bahan pertimbangan bagi konsumen dalam melakukan pembelian tidak bisa dikesampingkan oleh perusahaan, harga juga merupakan penentu keberhasilan suatu perusahaan karena harga menentukan seberapa besar keuntungan yang akan akan diperoleh perusahaan dari penjualan produknya baik berupa barang ataupun jasa. Menetapkan harga terlalu rendah akan mengurangi keuntungan yang diperoleh oleh perusahaan, namun jika harga terlalu tinggi akan menyebabkan penjualan akan menurun. Dengan melihat definisi harga diatas dapat disimpulkan bahwa harga adalah sejumlah uang yang harus dikeluarkan oleh konsumen untuk mendapatkan produk atau 
jasa yang dibelinya guna memenuhi kebutuhan dan keinginannya.

Pengukuran variabel harga berdasarkan pada terjangkau atau tidaknya harga, kesesuaian harga dan kapasitas isi/ukuran, kesesuaian harga dan cita rasa, kesesuaian harga dengan manfaat yang didapat dari produk Tahu - Tempe dan kesesuaian harga dengan kualitas dari produk Tahu - Tempe dimana berdasarkan Performance nilai rata-rata terendah yaitu 3,6 dan nilai rata-rata tertinggi yaitu 4,6 maka rangenya yaitu 4,1 dan berdasarkan Importance nilai rata-rata terendah yaitu 3,5 dan nilai rata-rata tertinggi yaitu 4,1 maka rangenya yaitu 3,8 . Penjelasan tentang kelima pengukuran dari Industri Tahu - Tempe "ABC" dan Industri Tahu -Tempe "XYZ" dapat dilihat pada kurva dibawah ini :

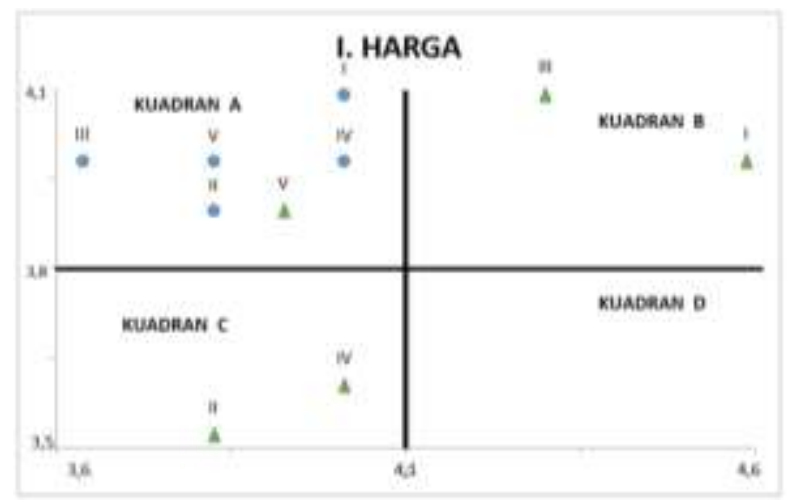

Gambar 1. Kurva IPA Harga Tahu - Tempe "ABC" dan Tahu - Tempe "XYZ"

Gambar 1 dapat dijelaskan tentang penilaian jumlah penjualan berdasarkan kelima aspek tersebut terkait dengan kualitas harga dari Industri "ABC" dan Industri "XYZ". Dimana pada Industri "ABC" di titik I dan III berada di kuadran B 'Keep Up The Good Work' yaitu terjangkau atau tidaknya harga dan kesesuaian harga dengan cita rasa dianggap sangat penting oleh konsumen dan memuaskan konsumen sehingga wajib dipertahankan. Pada titik II dan IV berada di kuadran C'Low Priority' yaitu kesesuaian harga dengan ukuran dan kesesuian harga dengan manfaat dianggap kurang penting atau bukan sesuatu yang diharapkan oleh konsumen dan tidak perlu menjadi prioritas karena pengaruhnya terhadap kepuasan konsumen sangat kecil namun pada titik V berada di kuadran A'Concentrate Here' yaitu kesesuaian harga dengan kualitas dianggap sangat penting oleh konsumen tetapi tidak memuaskan konsumen sehingga industri " $\mathrm{ABC}$ " harus memperbaiki-nya. Sedangkan secara keseluruhan industri "XYZ" berada pada kuadran A "concentrate Here" atau harga dari tahu-tempe "XYZ" menunjukkan faktor yang dianggap mem- pengaruhi pelanggan, dianggap sangat penting, namun harga tidak sesuai keinginan pelanggan sehingga tidak puas sehingga perlu perbaikan.

\section{Produk}

Produk merupakan hal yang diproduksi oleh tenaga kerja atau usaha. Produk juga merupakan salah satu aspek yang menentukan dalam kegiatan suatu usaha, karena tanpa produk suatu perusahaan/industri tidak dapat melakukan kegiatan untuk mencapai hasil yang diharapkan. Dalam mengembangkan sebuah program untuk mencapai pasar yang diiginkan, sebuah perusahaan/industri harus memulai dengan produk atau jasa yang dirancang untuk memuaskan keinginan konsumen. Maka dari itu perusahaan/industri harus berusaha mengambil hati para konsumen untuk memperlancar jalannya produksi dan jumlah suatu produk yang dihasilkan tergantung dari sumber daya yang ada dalam suatu perusahaan/industri dan akan mempengaruhi harga dan penjualan.

Penilaian berdasarkan jumlah penjualan produk pada kedua usaha ini dinilai berdasarkan lima variabel yaitu kebersihan dalam penyajian produk Tahu -Tempe, ketersediaan produk Tahu - Tempe, cita rasa produk Tahu - Tempe, tampilan fisik produk Tahu - Tempe, kelengkapan dan ketersediaan produk Tahu Tempe yang dijelaskan dengan menggunakan kurva IPA dan berdasarkan Performance nilai rata-rata terendah yaitu 3,1 dan nilai rata-rata tertinggi yaitu 4,3 maka rangenya yaitu 3,7 dan berdasarkan Importance nilai rata-rata terendah yaitu 3,4 dan nilai rata-rata tertinggi yaitu 4,2 maka rangenya yaitu 3,8 . Penjelasan tentang kelima pengukuran dari Industri Tahu - Tempe "ABC" dan Industri Tahu - Tempe "XYZ" dapat dilihat pada kurva berikut :

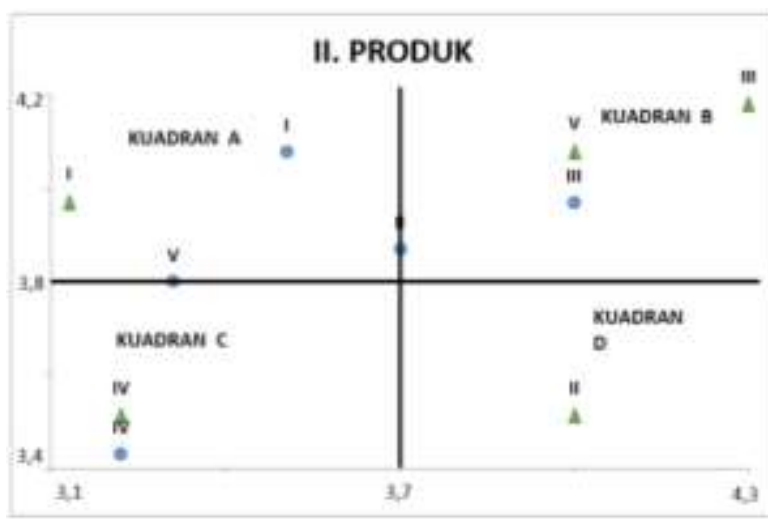

Gambar 2. Kurva IPA Produk Tahu - Tempe "ABC" dan Tahu - Tempe "XYZ"

Gambar 2 dapat dijelaskan tentang posisi daya saing dari kedua industri tersebut dimana dapat dijelaskan tentang penilaian jumlah penjualan 
berdasarkan kelima aspek tersebut terkait dengan kualitas produk dari Industri Tahu-Tempe "ABC" dan Industri Tahu-Tempe "XYZ". Pada Industri Tahu-Tempe "ABC" di titik I berada di kuadran A 'Concentrate Here' yaitu menunjukkan bahwa kebersihkan dalam penyajian produk sangat penting bagi konsumen tetapi tidak memuaskan sehingga Industri Tahu - Tempe "ABC" harus memperbaikinya. Pada titik II barada di kuadran D'Possible Overkill' yaitu menunjukkan bahwa ketersediaan produk Tahu-Tempe kurang penting dan tidak terlalu diharapkan oleh konsumen namun pemenuhannya terlalu berlebihan. Pada titik III dan V berada di Kuadran B'Keep Up The Good Work' yaitu menunjukkan bahwa cita rasa produk dan kelengkapan produk sangat penting dan memuaskan karena cita rasa yang gurih dan sedap memberikan keunggulan bagi industri ini serta kelengkapan bahan yang dipakai untuk membuat Tahu - Tempe sangan berkualitas yaitu dari kacang impor dan juga perlengkapan dalam pabrik lengkap dan produk juga diolah sendiri memakai alat yang sederhana tetapi kualitas yang didapat tidak kalah saing serta terjamin sehingga wajib dipertahankan, namun pada titik IV berada di kuadran C'Low Priority' yaitu tampilan fisik produk kurang penting atau bukan sesuatu yang diharapkan oleh konsumen dan tidak perlu menjadi prioritas karena pengaruhnya terhadap kepuasan konsumen sangat kecil. Sedangkan Industri Tahu - Tempe "XYZ" di titik I berada di kuadran A'Concentrate Here' dimana kebersihan dalam penyajian produk sangat penting bagi konsumen tetapi tidak memuaskan sehingga Industri Tahu-Tempe "XYZ" harus memperbaikinya. Pada titik II berada di antara kuadran A'Concentrate Here' dan kuadran B'Keep Up The Good Work' yang menunjukkan sebagian konsumen menilai ketersediaan produk Tahu-Tempe dianggap sangat penting oleh konsumen tetapi tidak memuaskan sehingga industri "XYZ" harus memperbaikinya dan sebagian konsumen menilai ketersediaan produk Tahu-Tempe dianggap sangat penting oleh konsumen dan memuaskan sehingga wajib dipertahankan. Pada titik IV berada di kuadran C 'Low Priority' dimana tampilan fisik produk kurang penting atau bukan sesuatu yang diharapkan oleh konsumen dan tidak perlu menjadi prioritas karena pengaruhnya terhadap kepuasan konsumen sangat kecil namun pada titik III berada di kuadran B 'Keep Up The Good Work' dimana cita rasa produk wajib dipertahankan dan dianggap sangat penting dan memuaskan karena cita rasa yang gurih dan sedap memberikan keunggulan bagi industri ini. Pada titik V berada diantara kuadran A'Concentrate Here' dan kuadran C'Low Priority' yang menunjukkan bahwa sebagian konsumen menilai kelengkapan produk dianggap sangat penting oleh konsumen tetapi tidak memuaskan sehingga industri "XYZ" harus memperbaikinya dan sebagian konsumen menilai kelengkapan produk kurang penting atau bukan sesuatu yang diharapkan oleh konsumen dan tidak perlu menjadi prioritas karena pengaruhnya terhadap kepuasan konsumen sangat kecil.

\section{Tempat}

Tempat merupakan berbagai kegiatan yang dilakukan oleh perusahaan atau industri untuk membuat produknya mudah diperoleh dan tersedia pada konsumen sasaran. Tempat juga dapat diartikan sebagai sarana yang diselenggarakan oleh pemerintah, swasta atau perorangan yang digunakan untuk kegiatan bagi masyarakat. Menentukan tempat harus melihat bagaimana fasilitas yang disediakan karena tempat berkaitan dengan fasilitas yang ditawarkan kepada konsumen.

Pengukuran variabel tempat berdasar-kan pada kebersihan ruangan di pabrik Tahu Tempe, kenyamanan ruangan pabrik, tampilan fisik ruangan pabrik, kelengkapan saranan dan fasilitas yang dimiliki pabrik, dan lokasi tempat pemasaran dimana berdasarkan Performance nilai rata-rata terendah yaitu 2,2 dan nilai ratarata tertinggi yaitu 4,4 maka rangenya yaitu 3,3 dan berdasarkan Importance nilai rata-rata terendah yaitu 3,2 dan nilai rata-rata tertinggi yaitu 4,6 maka rangenya yaitu 3,9. Penjelasan tentang kelima pengukuran dari Industri Tahu Tempe "ABC" dan Industri Tahu - Tempe "XYZ" dapat dilihat pada kurva dibawah ini :

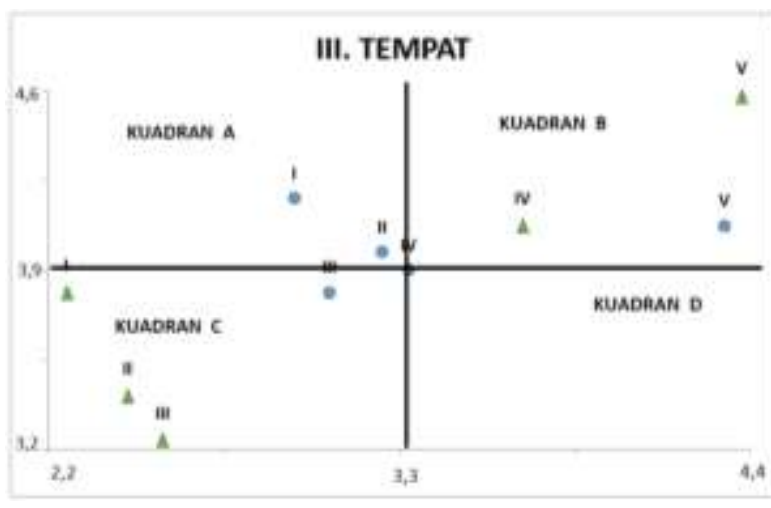

Gambar 3. Kurva IPA Tempat Tahu - Tempe "ABC" dan Tahu - Tempe "XYZ"

Gambar 3 dapat dijelaskan tentang penilaian jumlah penjualan berdasarkan kelima aspek tersebut terkait dengan tempat dari Industri Tahu - Tempe "ABC" dan industri Tahu - Tempe "XYZ". Pada industri "ABC" di titik I,II dan III 
berada di kuadran C'Low Priority' yaitu kebersihan ,kenyamanan dan tampilan fisik ruangan kurang penting atau bukan sesuatu yang diharapkan oleh konsumen namun memuaskan dan tidak perlu menjadi prioritas karena pengaruhnya terhadap kepuasan konsumen sangat kecil. Pada titik IV dan V berada di kuadran B'Keep Up The Good Work' yaitu menunjukkan bahwa kelengkapan alat produksi lengkap dan tempat sangat strategis dan dianggap sangat penting, memuaskan dan wajib dipertahankan. Sedangkan pada Industri "XYZ" di titik I dan II berada di kuadran A'Concentrate Here' yaitu menunjukkan bahwa kebersihan ruangan dan kenyamanan ruangan sangat penting tetapi tidak memuaskan konsumen sehingga harus di perbaiki. Pada titik III berada dikuadran C'Low Priority' yaitu menunjukkan bahwa tampilan fisik ruangan memuaskan namun kurang penting bagi konsumen dan tidak perlu menjadi prioritas karena pengaruhnya terhadap kepuasan konsumen sangat kecil. Pada titik IV berada di tengah garis performance dan importance yaitu tidak dikuadran A,B,C dan E. Namun pada titik $\mathrm{V}$ berada dikuadran $B$ 'Keep Up The Good Work' yaitu lokasi yang straregis dianggap sangat penting dan memuaskan konsumen serta wajib dipertahankan.

\section{Pelayanan}

Pelayanan secara umum adalah setiap kegiatan yang diperuntukan atau ditunjukan untuk memberikan kepuasan pada pelanggan, melalui pelayanan ini keinginan dan kebutuhan pelanggan dapat terpenuhi atau pelayanan adalah kegiatan yang dilakukan oleh seorang maupun sekelompok orang untuk memenuhi kebutuhan orang lain sesuai dengan prosedur dan system yang telah ditetapkan sebelumnya.

Pengukuran variabel pelayanan berdasarkan pada kecepatan dalam melayani konsumen, kesigapan pekerja dalam memberikan pelayanan dan menangani keluhan konsumen, pengetahuan pekerja mengenai produk Tahu - Tempe, penampilan fisik dari pekerja (kerapian berpakaian), dan keramahan pekerja dalam melayani konsumen. Berdasarkan Performance nilai rata-rata terendah yaitu 2,2 dan nilai rata-rata tertinggi yaitu 4,6 maka rangenya yaitu 3,4 dan Berdasarkan Importance nilai rata-rata terendah yaitu 3,4 dan nilai rata-rata tertinggi yaitu 4,4 maka rangenya yaitu 3,9. Penjelasan tentang kelima pengukuran dari Industri Tahu - Tempe
"ABC" dan Industri Tahu - Tempe "XYZ" dapat dilihat pada kurva dibawah ini:

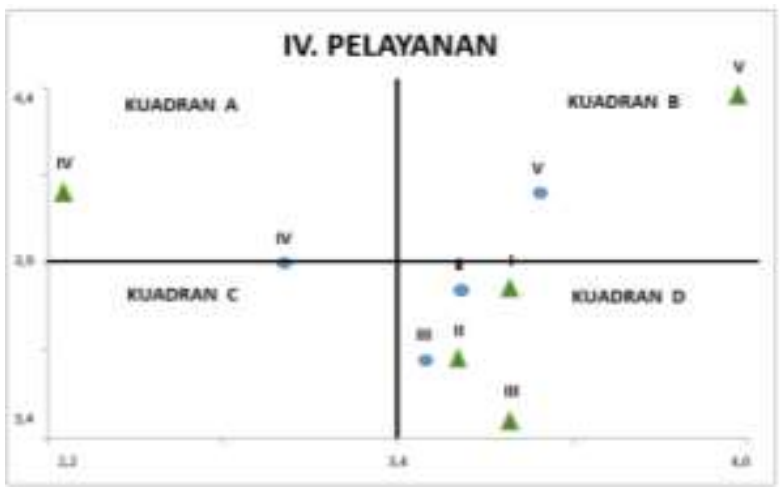

Gambar 4. Kurva IPA Pelayanan Tahu - Tempe "ABC" dan Tahu - Tempe "XYZ"

Gambar 4 dapat dijelaskan tentang penilaian jumlah penjualan berdasarkan kelima aspek tersebut terkait dengan kualitas pelayanan dari industri Tahu-Tempe "ABC" dan Industri Tahu-Tempe "XYZ". Pada Industri "ABC" di titik I,II dan III berada di kuadran D'Possible Overkill' yaitu menunjukkan bahwa kecepatan dalam melayani konsumen, kesigapan pekerja dalam memberikan pelayanan dan pengetahuan pekerja terhadap produk Tahu-Tempe dianggap kurang penting namun pemenuhannya terlalu berlebihan dan dapat di pertimbangkan untuk dikurangi demi efisiensi industri "ABC". Pada titik IV berada di kuadran $A$ 'Concentrate Here' yaitu kerapian berpakaian dari pekerja dianggap sangat penting oleh konsumen tetapi tidak memuaskan sehingga industri " $\mathrm{ABC}$ " harus memperbaikinya. Pada titik V berada di kuadran B'Keep Up The Good Work' yaitu menunjukkan bahwa keramahan pekerja dianggap sangat penting oleh konsumen dan memuaskan sehingga wajib dipertahankan. Sedangkan pada industri Tahu - Tempe "XYZ" di titik I,II dan III berada di kuadran D'Possible Overkill' yaitu menunjukkan bahwa kecepatan dalam melayani konsumen, kesigapan pekerja dan pengetahuan pekerja dianggap kurang penting dan tidak terlalu diharapkan konsumen namun pemenuhannya terlalu berlebihan dan dapat di pertimbangkan untuk dikurangi demi efisiensi industri "XYZ". Pada titik IV berada diantara kuadran A'Concentrate Here' dan kuadran C'Low Priority' yang menunjukkan sebagian konsumen menilai kerapian berpakaian dari pekerja dianggap sangat penting oleh konsumen tetapi tidak memuaskan sehingga industri "XYZ" harus memperbaikinya dan sebagian konsumen menilai 
kerapian berpakaian dari pekerja dianggap kurang penting atau bukan sesuatu yang diharapkan oleh konsumen namun memuaskan dan tidak perlu menjadi prioritas karena pengaruhnya terhadap kepuasan konsumen sangat kecil, namun pada titik V berada di kuadran B'Keep Up The Good Work' yaitu menunjukkan bahwa keramahan pekerja dianggap sangat penting oleh konsumen dan memuaskan sehingga wajib dipertahankan.

\section{KESIMPULAN DAN SARAN}

\section{Kesimpulan}

Dari hasil penelitian diperoleh bahwa harga yang ditawarkan Industri Tahu Tempe "ABC" dan Tahu - Tempe "XYZ" menunjukan penilaian yang berbeda, industri "ABC" dinilai sangat terjangkau dan cita rasa dinilai puas namun kualitas tidak memuaskan serta kapasitas dan manfaat dinilai tidak terlalu penting namun sangat berlebihan kepuasannya. Sedangkan industri "XYZ" menunjukkan harga yang ditawarkan tidak memuaskan dari semua aspek dan industri "XYZ" harus memperbaiki dengan segera, karena konsumen menilai semua aspek sangat penting. Dari segi produk baik untuk Industri Tahu - Tempe "ABC" dan Tahu - Tempe "XYZ" menunjukkan tingkat kepuasan yang berbeda dimana industri "ABC" terhadap konsumen memuaskan dari segi kebersihan dan kelengkapan namun dari segi kebersihan tidak memuaskan serta ketersediaan bahan baku sangat tidak memuaskan namun untuk tampilan produk memuaskan tetapi dinilai tidak penting bagi konsumen, sedangkan industri "XYZ" menunjukkan cita rasa produk memuaskan dan harus dipertahankan namun dari aspek kebersihan, ketersediaan produk dan kelengkapan dalam penyajian produk sangat penting bagi konsumen tetapi tidak memuaskan sehingga Industri Tahu-Tempe "XYZ" harus memperbaikinya sedangkan tampilan fisik produk kurang penting atau bukan sesuatu yang diharapkan oleh konsumen. Kemudian dari segi tempat yang digunakan Industri Tahu - Tempe "ABC" dan Industri Tahu -Tempe "XYZ" kurang baik dari tingkat kebersihan ruangan yang masih kurang bersih, kenyamanan ruangan yang masih terjangkau dari asap oleh olahan Tahu - Tempe dan suara mesin yang ribut, tampilan fisik ruangan juga kurang baik dan harus diperbaiki untuk Industri "ABC", maka Industri "ABC" kalah saing dengan Industri "XYZ", sedangkan ketersediaan peralatan produksi dan lokasi yang sangat strategis menunjukan sangat puas dan baik karena alat yang digunakan banyak dan lokasi pemasaran sangat strategis dekat dengan tempat kost, rumah makan dan pasar. Dari segi pelayanan yang diberikan oleh pekerja Industri Tahu - Tempe "ABC" dan Industri Tahu -Tempe "XYZ" baik itu dari kecepatan, kesigapan, pengetahuan dan keramahan sudah sangat memuaskan konsumen, hanya untuk industri "ABC" penampilan fisik dari pekerja tersebut kurang baik dari berpakaian dan kerapian yang ditunjukan belum memuaskan pembeli namun sangat penting bagi konsumen, sedangkan untuk industri "XYZ" konsumen menilai sebagian sudah memuaskan dari berpakaian dan kerapian dan sebagian tidak memuaskan dari berpakaian dan kerapian dan aspek ini dianggap sangat penting bagi konsumen.

\section{Saran}

Berdasarkan penelitian yang telah dilakukan akan kesimpulan yang di kemukakan, maka peneliti mengemukakan beberapa saran. Kiranya saran ini dapat berguna bagi Industri Tahu - Tempe "ABC" dan Industri Tahu Tempe "XYZ" untuk memperbaiki aspekaspek yang masih kurang yaitu aspek harga dimana konsumen menilai harga belum terjangkau, kebersihan dari produk, tempat dimana kurangnya kebersihan ruangan pabrik yang membuat kekurang dari kedua industri serta tampilan fisik ruangan harus diperbaiki dan memperluas area transaksi pembelian Tahu - Tempe yang kurang luas dan kerapian pekerja harus diperbaiki. Kemudian kepada lembaga pemerintahan agar lebih memperhatikan dalam pengembangan usaha Tahu - Tempe yang merupakan industri favorite (kesukaan) masyarakat yang ada di Sulawesi Utara khususnya Kelurahan Kleak, dilihat dari aspek tempat yang sangat tidak memuaskan sehingga pemerintah harus campur tangan dalam membantu industri tersebut. 


\section{DAFTAR PUSTAKA}

Damardjati, D.S., Marwoto, D.K.S. Swastika, D.M. Arsyad, dan Y. Hilman. 2005. Prospek dan Arah Pengembangan Agribisnis Kedelai. Badan Litbang Pertanian. Departemen Pertanian, Jakarta.

Ditjentan., 2004. Profil Kedelai (Glycine max). Buku 1. Direktorat Kacang Kacangan dan Umbi-Umbian. Departemen Pertanian. Jakarta.
Hariyadi., P. 2014. Pengembangan Industri Pangan Sebagai Strategi diversifikasi dan peningkatan daya saing produk pangan. (https://www.researchgate.net/publication/26 7329132_pengembangan_industri_pangan_se bagai strategi diversifikasi dan peningkatan daya saing produk pangan) di akses pada hari Rabu 12 september 2018.

Sugiyono., 2009. Metode Penelitian Kuantitatif, Kualitatif dan R\&D, Bandung: Alfabeta.

Tangendjaja, B., Y. Yusdja, dan Nyak Ilham. 2003. Analisis Ekonomi Permintaan Jagung untuk Pakan. Dalam: Kasryno et al. (Eds.). Ekonomi Jagung Indonesia. Badan Litbang Pertanian, Jakarta. 